\title{
Dangdut and the Concept of Khamr: Hermeneutic Analysis of Dangdut Koplo Performance
}

\author{
Nurulfatmi Amzy ${ }^{1}$, Pandu Pramudita ${ }^{2}$, and D Pratama ${ }^{3}$ \\ Faculty of Language and Art, Universitas Indraprasta PGRI, Jakarta Selatan, Indonesia ${ }^{1,2,3}$ \\ \{nurulfatmiamzy@gmail.com $\left.{ }^{1}\right\}$
}

\begin{abstract}
Dangdut is a proof that all levels of society in Indonesia can enjoy music. The lyrics of Dangdut that is honest and close to daily life occurrences make Dangdut easy to understand for everyone, including those coming from lower to the middle class. But that very reason makes the gedongan people, those who came from middle-upper class, mocks Dangdut as music for the plebs. The mockery became increasingly common when Dangdut was identified as erotic music performances. Dangdut music, created by the combination of the sound of the drum, single organ, and flute, was accompanied by erotic dances performed by the dangdut singer. This performance bewitched the audience, especially men. They seemed to feel "high" and then willingly gave sawer, the act of giving money to the singer, without thinking about their primary needs. This paper raises the question of whether Dangdut Koplo can be considered as Khamr, a form of alcoholic substance if the performance has an intoxicating effect. By using the hermeneutic method, this study will analyze the phenomenon of Dangdut Koplo performance and the meaning behind the term of Khamr itself. The result shows that although Dangdut Koplo performance and khamr are two different things, there is a connectedness between the intoxicating effect of Dangdut Koplo performances and the concept of Khamr.
\end{abstract}

Keywords: Music Dangdut, Dangdut Koplo, Khamr

\section{Introduction}

"Dangdut is the music of my country," is one of the lyrics from the song performed by a vocal group from Indonesia a few years ago. The word "my country" clearly refers to Indonesia as a country. Indonesia cannot be separated from the history of dangdut music. Thus, many people perceive Dangdut as an identity for this nation. Dangdut performances often called dangdutan, are commonly found in many public activities in society, such as when there is a marriage ceremony, village festivals, and national commemorations. For some people, Dangdut performances are a means of entertainment and a leisure activity to release tensions after work.

However, Dangdut music has often been identified with vulgar erotic performances lately. Singers who take part in Dangdut performances often wear minimal clothing. Aside from the clothes, the singers also danced while moving their body seductively on the stage. Because of this, men who dominate the lines in the audience will swarm and push each other to be able to 
occupy the front row near the stage. This kind of Dangdut performance is then commonly referred to as Dangdut Koplo performance [1].

The phenomenon of the crowd pushing each other to get closer to the stage without regard to personal safety and the mass dancing performed by the audience raises an argument that Dangdut Koplo can make a person behaved out of control, as though he lost his consciousness. In Islam, there exists the term Khamr which is used to refer to intoxicating things such as wine and alcohols. However, This paper raises the question on whether Dangdut Koplo can be considered as Khamr if the performance has an intoxicating effect. This paper will examine the concept behind Dangdut and Dangdut Koplo and the meaning of Khamr itself and what is included in it using hermeneutics method proposed by Gadamer. At the stage of conclusions, the study will then make a comparison between the two by juxtaposing their genuine meaning behind the concept of Dangdut Koplo and the concept of Khamr.

\section{Method}

This paper will focus on interpreting the meaning behind the terms of Dangdut, Dangdut Koplo, and Khamr by using the hermeneutic research method proposed by Gadamer. The hermeneutics research method is used to understand the concept and solve the problem of ambiguity between the intoxicating effects in Dangdut Koplo performance and those intended by the term Khamr. Although hermeneutics is commonly seen as the process of understanding the text in the form of writing, the text in hermeneutics can also be understood as a reality created by the daily phenomenon. Hermeneutics as the process of understanding the text proposed by Gadamer involved three levels of understanding [2].

First, understanding as an activity of reason. To understand the meaning of a text means to think about it in order to see it more clearly. Second, understanding as something practical. To understand does not mean just mastering the theory, but also being able to apply and explain it. A chef can be said to understand the art of cuisine because he does not only understand the theory of spices but also good at applying all the knowledge of these spices into a food. This is in line with what Plato said that acting in a good manner is not the same as knowing the essence of the good. Third, understanding as a mean of an agreement. If someone is able to understand the text, then he has agreed with the intention conveyed by the author. However, Gadamer said that the author's original intent was still a secondary matter, while the most important thing was the underlying theme of the conversation. It means that the original intent of the author still exists, but in interpreting the text, the context of the conversation must also be considered. The principle of hermeneutics proposed by Gadamer is a form of classical logic; when we want to understand something as a whole, start from understanding the parts first. Gadamer applies this logic into the process of understanding the text. The aim is to get a thorough understanding of a more comprehensive and contextual framework, not merely to understand the meaning of what the author says [2].

\section{Discussion}

\subsection{Dangdut}

Dangdut is a type of music that developed in Jakarta in the early 1970s. Broadcasted through local and national radio, and found its way into the society through tapes and musical films, it does not take long for Dangdut to become one of the most popular music genres in Indonesia. The core element of Dangdut lies in Malay orchestration which is strongly influenced by the music found in Indian and Middle Eastern films that were popular in Indonesia in the 1950s and 1960s. The basic musical instruments used in Dangdut are guitar, bass, drum, keyboard, mandolin, and tambourine. In addition to these musical instruments, there are two instrumental accompaniments that make Dangdut different from other types of music, namely Gendang (which is similar to Tabla from North India) and Suling. Rhoma Irama is one of the most important singers in the world of Dangdut. He reinforced Dangdut music and popularized it through live concerts and recordings in the 1970s. Frederick (in Weintraub) says 
that the Dangdut brought by Rhoma Irama has lyrics with a theme about everyday life, love, and social criticism related to the social class disparities [3].

To understand how the lyrics created by Rhoma Irama plays an important role in defining the concept of Dangdut, below is an example of the lyrics to one of his song titled "Hak Azasi" (human rights):

\section{Hormati hak azasi manusia}

Karena itu fitrah manusia

Kita semua bebas memilih

Jalan hidup yang disukai

Tuhanpun tidak memaksakan

Apa yang hamba-Nya lakukan

Kebebasan beragama

\author{
Itu hak azasi \\ Kebebasan berbicara \\ Itu hak azasi \\ Kita bebas untuk melakukan segala-galanya \\ Asal saja tidak bertentangan tentang \\ Pancasila \\ (Hak Azasi) [4]
}

The lyrics above tell about the rights of each person as a human. Every human being is created to humanize each other as human beings. To humanize means to let people choose for themselves what their life deserves. Humans are creatures capable of rational thinking. If one has healthy reasoning, then he will be able to determine the good from the bad. Maintaining humanity or humanizing a person is placing him as someone who is capable of thinking and acting, making his life fully under his own control.

Frederick said that the lyrics of "Hak Azasi" shows that Dangdut put forward a clear opinion or understanding of a matter [4]. Meanwhile, Titik Puspa argues that Dangdut is very close to the people. Then, Weintraub explained that the closeness with the people was based on 1) melody, rhythm, and Malay vocal color, 2) using Indonesian in the lyrics, 3) offering quite simple dances, 4) using honest and easy to understand lyrics, and 5) the lyrics tell about the everyday life of ordinary people [3].

\subsection{Dangdut Koplo}

Weintraub explained that Dangdut Koplo borrows its name from a drug called Koplo, a hallucinogenic drug that is sold cheaply in Indonesia. The audience realized that the music provided by Dangdut Koplogives the same experience as consuming the Koplo pill, Making people feeling "high".Dangdut Koplo was articulated as the spirit of the era after the fall of Soeharto regime: fast, chaotic, even in threats to become an out of control situation, but full of passion and hope [1].

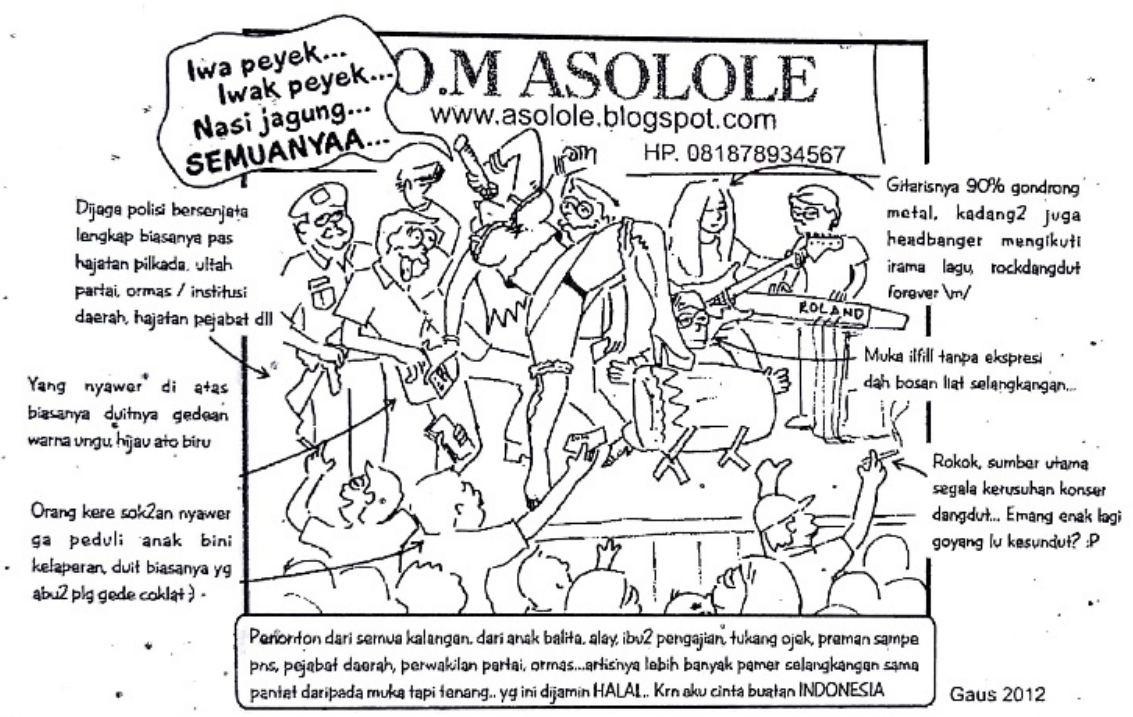

Figure 1. The Illustration of Dangdut Koplo performance 
Figure 1 shows an illustration of how regular Dangdut Koplo performances are held. From this illustration, it can be noted that the performances of Dangdut Koplo are usually guarded by police and law officer, especially during political events such as local elections, the birthday celebration of political parties, a celebration held by the community or regional organizations, and celebrations held by local officials. In terms of musical format, it can be seen in figure 1 that the performance of Dangdut Koplo uses organs or keyboards, drums, and guitars.

Dangdut Koplo performances are also identical to sawer, the act of giving money to singers. The people who are on stage are usually the audience who gave the singers more money. Figure 1 shows a man sticking his tongue while giving money to the singers. The illustration associates this act of sawer with the color of purple, green, and blue. The color purple stands for Rp. 10,000, -; Green for Rp. 20,000, -, and; Blue for Rp. 50,000, - [1]. The audience standing in front of the stage will also give money, but not greater than the one on the stage, which is usually amounted to only Rp.2,000 to Rp. 5,000, -

Weintraub said that the name of the people on stage would usually be mentioned by the singer personally and that would raise their status. They then play and flirt with the singer and give the singer their money. Usually, the money will be put on the singer's clothes, in the bra, and even in the mouth [1]

The illustration in figure 1 also stated that the audience of Dangdut Koplo performances came from all classes of society, from children, mothers, motorcycle taxi drivers, to civil servants. Then, figure 1 illustrates the picture of the audience under the stage dancing with their thumbs up, a characteristic of mass dancing in dangdutan. The singer was illustrated as wearing minimal clothing, raises one leg and is placed on the drum in order to show her private parts to the audience. In the information contained in the illustration, it is clearly understood that the singer of Dangdut Koplo exhibits more of her private parts than her own face. However, the illustration continued on with the statement, "But calm down, this one is HALAL because I love things made in INDONESIA".

Weintraub then added that what is illustrated in the picture above is the main component that must be present in the performance of Dangdut Koplo: female singers will dance erotically on the stage by shaking their hips and occasionally shaking their chests. However, what needs to be underlined is that basically Dangdut Koplo does not necessitate the singer to dance erotically. This phenomenon happened because Dangdut performances merge with traditional dances, where erotic movements often occurred. Erotic movements in traditional dances have long been performed in many events in villages in Java. At these events, women sing, then men give sawer as a payment for their dance. Weintraub argued that Dangdut Koplo is a matter of style, not about the contents of the song itself. Therefore, all songs can be merged into the form of Dangdut Koplo. The performance ofDangdut Koplo can play songs from various genres of music. When performing, they usually see who will be the audience first. So, the song will follow the taste of the audience lining up in front of them. Afterward, this will be made more captivating by adding erotic movements danced by the singer in the Dangdut Koplo performance. That is what makes the audience feel thatDangdut Koplo is an interesting show to watch [1].

\subsection{Khamr: Alcoholic drinks or all things intoxicating?}

Khamr comes from Arabic which means to approach and to mix. Khamr can also mean covering, so khamr can be interpreted as a type of drink that covers the reasoning of a person. 
According to Abu Hanifah, khamr is a form of drinks created from grape juice that is cooked to a boil and release foams. The juice from these foams is the one which contains intoxicating substances. Meanwhile, according to al-Safi'I and Jumhur, khamr is all drinks that contain intoxicating elements, not just those made from grape juice [5].

This statement of al-Safi'I follow the statement of the Prophet Muhammad SAW (narrated by Muslim) that what is included in khamr is not just wine. This is because khamr itself has the meaning of "intoxicating things", no matter the form or name used to refer to these intoxicating things. One time, the Prophet Muhammad SAW was asked about certain drinks which were fermented so that they contain the alcoholic substance. Then the Prophet added, "all intoxicants are khamr and every khamr is haram." That is because Khamr blurs the mind. In any measure, many or even just a little, can not change the status of khamr as something that is deemed as haram [6]

\section{Conclusion}

From the explanation above, it can be understood that DangdutKoplo is an extension of the Dangdut itself, which is emphasized in the style of the Dangdut performance. There are elements that present in the performance of Dangdut Koplo, erotic dances, and the act of sawer. Dangdut music with the drum and the flute alone can attract the audience to enjoy the performance to the point of moving their body. Even if it's just in the form of moving their thumbs up, as a typical move in Dangdut performance, this is an indication that Dangdut music can touch the soul of its listeners. In the Dangdut Koplo performance, the pleasure given by Dangdut music was added by the erotic dances and the act of sawer. It perfected the pleasure given to the eyes and ears captured by these stimuli so much so that it manifests in the mind of the audience.

The illustration of the Dangdut Koplo performance shown in figure 1 clearly indicates that the performance of Dangdut Koplo can make people forget about their primary and family needs, so they are willing to use their money to engage in the act of sawer. Moreover, the crowd pushing each other in front of the stage added a particular excitement to the atmosphere. The audience seems to feel"high" and forgot about the reality of his life. Because of this, Dangdut performances such as that are called Koplo, borrowing the name from an inexpensive hallucinogenic drug that is sold freely.

After the study examines the meaning of khamr and Dangdut Koplo itself, it is found that both are completely different things. Khamr is something physical. Although it was referring to the red wine at first, the understanding of khamr was extended to any type of drinks that can blur consciousness. That is, khamr only refers to drinks, it only refers to something with a physical form. However, Dangdut Koplo performance is a show, a spectacle. There is no physical manifestation; it only manifests in a form of musical performance activity that seems to have the power of "magic" that can seduce the audience.

However, despite the difference between the two, if viewed in the perspective of Islam, both of them include things that could potentially damage and even eliminate life and its livings. At least, there are five important points that must be safeguarded by humans so that their lives continue to run according to what they should be, namely religion, soul, descent, wealth, and reason [7]. Meanwhile, both khamr and Dangdut Koplo, seen from the effect, have the potential to blur or even eliminate human consciousness and reasons. If human lost all reason, a human would not able to act as humanely as possible. 


\section{References}

[1] A. N. Weintraub, "The Sound and Spectacle of Dangdut Koplo: Genre and CounterGenre in East Java, Indonesia," Asian Music, vol. 44, no. 2, pp. 160-194, 2013.

[2] A. A. Reza and Wattimena, "Berbagai Bentuk Metode Berfilsafat: Buku Ajar Metode Penelitian Filsafat," in Sebuah Tinjauan Historis Sistematis Dari Masa Yunani Kuno Sampai Posmodernisme, Yogyakarta: Kanisius, 2013, pp. 127-241.

[3] A. N. Weintraub, "Dangdut Soul: Who are 'the People' in Indonesian Popular Music?," Asian J. Commun., vol. 16, no. 4, pp. 411-431, Dec. 2006.

[4] W. H. Frederick, "Rhoma Irama and the Dangdut Style: Aspects of Contemporary Indonesian Popular Culture," Indonesia, vol. 34, Oct. 1982.

[5] A. J. Malik, "Sejarah Sosial Hukuman Peminum Khamr," Al-Daulah, vol. 3, no. 1, pp. 42-56, 2013.

[6] Y. Malik Al-Qaradawi, The Lawful and Prohibited in Islam. Indiana: American Trust Publications, 1999.

[7] A. Kasdi, "Maqasyid Syari'ah Perspektif Pemikiran Imam Syatibi Dalam Kitab AlMuwafaqat," Yudisia, vol. 5, no. 1, pp. 46-63, 2014. 